\title{
A Stakeholder-Guided Collaborative Approach to Improve Water Quality in a Nutrient Surplus Watershed
}

\author{
Hector German Rodriguez ${ }^{1}$, Jennie Popp ${ }^{1}$, Edward Gbur², John Pennington ${ }^{3}$ \\ ${ }^{1}$ Department of Agricultural Economics and Agribusiness, University of Arkansas, Fayetteville, USA \\ ${ }^{2}$ Agricultural Statistics Laboratory, University of Arkansas, Fayetteville, USA \\ ${ }^{3}$ Beaver Watershed Alliance, Fayetteville, USA \\ Email: hrodrig@uark.edu, jhpopp@uark.edu, egbur@uark.edu, john@beaverwatershedalliance.org
}

Received 13 February 2014; revised 11 March 2014; accepted 9 April 2014

Copyright (C) 2014 by authors and Scientific Research Publishing Inc.

This work is licensed under the Creative Commons Attribution International License (CC BY).

http://creativecommons.org/licenses/by/4.0/

(c) (i) Open Access

\section{Abstract}

The need for water quality improvement in nutrient surplus watersheds is a pressing issue on the agenda of some government agencies and environmental organizations. Including the water quality perceptions of different affected stakeholder groups in the decision-making process may help in addressing this issue. Unfortunately, there is a lack of published research focusing specifically on understanding how Arkansas stakeholders' perceptions of water quality issues can be used to build and implement comprehensive and workable water quality management plans. Therefore, the objective of this study was to use a stakeholder-guided collaborative approach to help research and outreach personnel to understand water quality perceptions of key stakeholders and to integrate stakeholder engagement in both the decision-making process and in the implementation of water quality management strategies within the Lincoln Lake Watershed in northwest Arkansas. Two key stakeholder groups (i.e., Locals-residents and agricultural producers-and Outsiders-water quality specialist across the state) were surveyed to assess their perceptions regarding: 1) causes of watershed water quality problems, 2) parties responsible for water quality improvement, 3) effectiveness and affordability of best management practices to reduce water quality degradation, and 4) the stakeholders' interactions with county, state and federal government. A total of 209 complete surveys (49\% response rate) were received. Survey responses were compared to determine if significant differences existed between the two stakeholder groups' perceptions of water quality performing Fisher's exact tests. Results from the study showed that water quality is still perceived as an issue in the Lincoln Lake Watershed. Significant differences were found between the two stakeholder groups' perceptions regarding: 1) different groups' contributions to water degradation, 2) groups' responsibilities for cleanup, 3) effectiveness of five best management practices, 4) affordability of four best management practices, and 5) what level

\footnotetext{
${ }^{*}$ Corresponding author.
}

How to cite this paper: Rodriguez, H.G., et al. (2014) A Stakeholder-Guided Collaborative Approach to Improve Water Quality in a Nutrient Surplus Watershed. Journal of Water Resource and Protection, 6, 571-582. 
of government (i.e., county, state, federal) best represents Locals' water quality needs and concerns. The lessons learned from this collaborative approach helped identifying Locals' important knowledge gaps regarding water quality and best management practices effectiveness. Consequently, awareness and education campaigns in conjunction with a stewardship recognition program were conducted to encourage appropriate water conservation strategies within the Lincoln Lake watershed and its adjacent areas.

\section{Keywords}

Stakeholders' Perceptions, Environmental Decision Making, Best Management Practices, Nutrient Surplus Watershed, Watershed Management

\section{Introduction}

\subsection{Water Quality Improvement and the Decision-Making Process}

Water quality improvements facilitated by policy action is pressing need in many nutrient surplus watersheds. In recent years, political and technical factors (i.e., water quality modeling/monitoring of nutrient, pesticide and sediment concentrations in streams and rivers) have influenced environmental policy changes in the United States [1]-[5]. Frameworks for effective environmental policy are complex because they must deal simultaneously with environmental, economic, and social concerns and the varying interests of different stakeholders [3] [6].

One further complicating factor is the difference between the perception and reality of stakeholders' inclusion in the decision-making process. The inclusion of several stakeholder groups, with their different interests and perceptions, contributes to improve the decision-making process [7]. However, due to the complexities mentioned above some stakeholders may be excluded [8]. Examples of this phenomenon can be seen when reviewing water quality management systems [3].

Policy goals, institutional goals and interest group goals may be viewed differently depending on the perspectives and biases of those involved in the formulation and implementation processes [9]. Additionally, stakeholders' interests vary based on, among other things, the potential favorable or unfavorable outcome obtained from a policy change and its direct and indirect effects. In fact, key stakeholders could oppose a water policy that has potential to adversely affect them [6].

Although regulation is a common policy tool used to address water pollution issues [2] [10]-[13], several government agencies encourage the implementation of best management practices (BMPs) through a voluntary adoption approach [2] [4] [11] [13]. From the institutional point of view, agricultural producers, other watershed residents and the public could benefit greatly and directly from a behavioral change toward better participation in the water conservation programs provided by county, state or federal agencies [1] [2] [14]. However, collective action depends on trust (Imperial 2005). So, if some in the group cooperate, others are more likely to cooperate too [2]. For instance, by providing cost-share programs and delivering information about the benefits of BMP adoption, county, state and federal organizations could improve trust and cooperation from stakeholders [11] [13].

\subsection{Water Quality Management in Arkansas}

The perception of water problems can differ across stakeholder groups [2] [6] [15]. Even with consensus that a water quality problem exists, each group can have its own objectives for management that may conflict with the objectives of one or more other groups [16]. In nutrient surplus watersheds in Arkansas, there are numerous groups with an interest in addressing water quality issues. In fact, there are more than twenty organizations with responsibility for preserving the state's water quantity, quality and public health [17]. Despite considerable effort to include key stakeholders in the decision-making process of preserving the quality of water resources in Arkansas, there is a lack of published research focusing specifically on understanding how Arkansas stakeholders' perceptions of water quality issues can be used to build and implement comprehensive and workable water quality management plans.

In 2006, the University of Arkansas (UA) Division of Agriculture was awarded a USDA CSREES Conserva- 
tion Effects Assessment Project (CEAP) grant. The overall purpose of this multidisciplinary project was to understand the relationship between BMPs and water quality in the Lincoln Lake watershed (LLW) in Northwest Arkansas. Hoag et al. gives a more detailed description of this project [18]. A specific goal was to assess the perceptions of different LLW stakeholders as well as county, state, and federal water quality specialists and regulators on water quality and the effectiveness of agricultural BMPs. This was a multi-institution effort that also included Purdue University, the Natural Resource Conservation Service, the Arkansas Natural Resource Commission, and Association of Conservation Districts.

\subsection{Research Purpose}

This study presents the results of a stakeholder-guided collaborative approach used to help research and outreach personnel to understand water quality perceptions of key stakeholders and to integrate stakeholder engagement in both the decision-making process and in the implementation of water quality management strategies. Two key stakeholder groups were surveyed to assess their perceptions regarding: 1) causes of watershed water quality problems, 2) parties responsible for water quality improvement, 3) effectiveness and affordability of BMPs to reduce water quality degradation, and 4) the stakeholders' interactions with county, state and federal government in setting and enforcing relevant water quality management policies. The lessons learned from this collaborative approach helped to identify appropriate strategies to increase awareness and implementation of BMPs enhancing the problem-solving capacity of stakeholders in this troubled watershed.

\section{Materials and Methods}

\section{The Lincoln Lake Watershed (LLW)}

The LLW in Northwest Arkansas is a subbasin of the Illinois River watershed that includes areas of both Northwest Arkansas and Northeast Oklahoma. The drainage area of the LLW is approximately $32 \mathrm{~km}^{2}\left(12 \mathrm{mi}^{2}\right)$. The dominant agricultural activities in the watershed are beef cattle and poultry operations. For a more detailed description of this watershed, see [19]. Nonpoint source (NPS) transport of nutrients (especially phosphorous), sediment, and pathogens from surface applied animal manure is a major concern [20] [21].

For this study, key stakeholders were divided into two groups: 1) watershed Locals and 2) Outsiders. Locals were comprised of two subgroups: agricultural producers (who own or operate land within the watershed) and other watershed residents (defined as households, business owners and other landowners). Outsiders were defined as natural resource specialists or water regulators from several county, state and federal institutions within the state who have knowledge of, or authority for, water quality management in the watershed.

Washington County Tax Assessor's Office records were used to identify 75 agricultural producers and 243 residents (Locals) in the LLW. One hundred and sixty water quality specialists (Outsiders) were identified through appropriate government agencies and academic institutions within the state. A stakeholder focus group, consisting of a county judge, five farmers, and two residents from an adjoining subwatershed, was formed to advise the project team on data collection and analysis. Survey data were collected in three different ways.

First, agricultural producers were interviewed in person by UA Cooperative Extension Service personnel. Second, residents were asked to complete a survey during watershed stakeholder meetings. Surveys were later mailed to residents absent from these meetings. Finally, specialists were mailed their surveys.

The survey questionnaires consisted of four or six sections depending on the stakeholder group surveyed. Some questions were developed specifically to gather the perceptions and behaviors of each stakeholder group regarding the four primary issues listed previously. However, when it was pertinent, the information was disaggregated to compare the Locals' subgroups (i.e., compare agricultural producers to other watershed residents) or to compare a Locals' subgroup to the Outsiders (i.e., compare agricultural producers to water quality specialists). Survey responses were compared to determine if significant differences existed between the two stakeholder groups' perceptions of water quality performing Fisher's exact tests to compare the distributions of responses from the two stakeholder groups.

\section{Results}

\subsection{Survey Demographic Analysis}

In total, of the 478 surveys distributed either by mail or in person, 209 usable responses (49\%) were received. 
From the Locals group, 131 survey responses were received. Sixty-three out of the 75 agricultural producers (84\%) completed the survey. Their primary agricultural activities included beef cattle, hay, pasture, and broiler production. Sixty-eight out of 243 residents (28\%) completed the survey. The majority of these respondents (81\%) were individuals who had their primary residence in the watershed.

Seventy-eight out of 160 (or 49\%) of the Outsiders completed the questionnaire. They represented six institutions: the UA Division of Agriculture Experiment Station (11\%), UA Division of Agriculture Cooperative Extension Service (29\%), Arkansas Conservation Districts (8\%), Natural Resources Conservation Service (25\%), Arkansas Department of Environmental Quality (8\%) and the Arkansas Natural Resources Commission (19\%).

\subsection{Perceptions Specifically Regarding Water Quality Problems in the Lincoln Lake Watershed}

Several studies have shown long-term trend improvements in water quality in the watershed since mid-1990s [22] and early 2000s [23]. Two recent studies have shown that overall flow-adjusted concentrations of phosphorus (the main pollutant of concern in LLW) have been decreasing from the Beatty Branch, Upper Moores Creek, and Moores Creek from 1992 to 2007 [19] and the Illinois River watershed from 1997 to 2010 [24]. However, the survey findings showed that the perceptions of water quality in the LLW may differ from this reality.

Locals and only those Outsiders familiar with the LLW (i.e., Lincoln Lake, Moores Creek and Beatty Branch) were asked their perceptions regarding the existence of water quality problems in the watershed. Of the 131 Locals respondents, 129 individuals answered this question. Only 18 out of 78 Outsiders (23\%) were familiar enough with the LLW to answer the survey questions specifically related to the LLW. A Fisher's exact test found significant differences between the distributions of responses of Locals and Outsiders regarding their perception of the water quality in each of the three bodies of water analyzed: Lincoln Lake, Beatty Branch and Moores Creek. Approximately $26 \%$ of the Locals and $72 \%$ of the Outsiders agreed that water quality problems existed in Lincoln Lake (Table 1).

Similarly for all three bodies of water, a greater percentage of Outsiders perceived that water quality problems existed than Locals did. Nevertheless, when groups were asked about their perceptions regarding different water uses (i.e., drinking, fishing, and swimming) in the three water bodies, no significant differences between stakeholders' responses were found (Tables 2-4).

In fact, the majority of the Locals and Outsiders respondents believed the water quality in the LLW was acceptable for drinking, once treated (Table 2) and fishing (Table 3). Respondents seemed more neutral in their perception that water was good for swimming (Table 4).

\subsection{Perceptions Regarding Water Degradation Contributions and Clean up Responsibilities}

Locals and Outsiders were asked questions about contributions to, and responsibilities for, cleaning up water quality issues. Both groups were asked specifically about their perceptions of the contributions of different

Table 1. General perceptions that water quality problems exist in the Lincoln Lake watershed (percentage of respondents).

\begin{tabular}{ccccccc}
\hline \multirow{2}{*}{ Level $^{\mathbf{a}}$} & \multicolumn{2}{c}{$\begin{array}{c}\text { Lincoln Lake } \\
(\mathbf{p}=\mathbf{0 . 0 0 1 0})^{\mathbf{b}}\end{array}$} & \multicolumn{2}{c}{$\begin{array}{c}\text { Moores Creek } \\
(\mathbf{p}=\mathbf{0 . 0 0 0 4})^{\mathbf{c}}\end{array}$} & \multicolumn{2}{c}{$\begin{array}{c}\text { Beatty Branch } \\
(\mathbf{p}=\mathbf{0 . 0 0 0 7})^{\mathbf{d}}\end{array}$} \\
\cline { 2 - 7 } & Locals & Outsiders & Locals & Outsiders & Locals & Outsiders \\
\hline Agree & 26.4 & 72.2 & 23.0 & 66.7 & 17.0 & 55.6 \\
Neutral & 36.4 & 16.7 & 39.3 & 27.8 & 45.5 & 38.9 \\
Disagree & 37.2 & 11.1 & 37.7 & 5.6 & 37.5 & 5.6 \\
\hline
\end{tabular}

${ }^{\mathrm{a}}$ Table entry as a percentage of respondents in that group selecting that response. ${ }^{\mathrm{b}}$ Response group includes 129 of the 131 Locals and 18 of 18 Outsiders. ${ }^{c}$ Response group includes 122 of the 131 Locals and 18 of 18 Outsiders. ${ }^{\mathrm{d}}$ Response group includes 112 of the 131 Locals and 18 of 18 Outsiders. 
Table 2. General perceptions that water is good for drinking (if treated) in the Lincoln Lake watershed, lakes and streams (percentage of respondents).

\begin{tabular}{ccccccc}
\hline \multirow{2}{*}{ Level $^{\mathbf{a}}$} & \multicolumn{2}{c}{$\begin{array}{c}\text { Lincoln Lake } \\
(\mathbf{p}>\mathbf{0 . 9 9 9 9})^{\mathbf{b}}\end{array}$} & \multicolumn{2}{c}{$\begin{array}{c}\text { Moores Creek } \\
(\mathbf{p}=\mathbf{0 . 2 8 4 0})^{\mathbf{c}}\end{array}$} & \multicolumn{2}{c}{$\begin{array}{c}\text { Beatty Branch } \\
(\mathbf{p}=\mathbf{0 . 5 0 3 7})^{\mathbf{d}}\end{array}$} \\
\cline { 2 - 7 } & Locals & Outsiders & Locals & Outsiders & Locals & Outsiders \\
\hline Agree & 70.1 & 72.2 & 67.2 & 61.1 & 64.0 & 55.6 \\
Neutral & 19.7 & 16.7 & 23.8 & 16.7 & 27.2 & 27.8 \\
Disagree & 10.2 & 11.1 & 9.0 & 22.2 & 8.8 & 16.7 \\
\hline
\end{tabular}

${ }^{\mathrm{a}}$ Table entry as a percentage of respondents in that group selecting that response. ${ }^{\mathrm{b}}$ Response group includes 127 of the 131 Locals and 18 of 18 Outsiders. 'Response group includes 122 of the 131 Locals and 18 of 18 Outsiders. ${ }^{\mathrm{d}}$ Response group includes 114 of the 131 Locals and 18 of 18 Outsiders.

Table 3. General perceptions that water is good for fishing in the Lincoln Lake watershed, lakes and streams (percentage of respondents).

\begin{tabular}{ccccccc}
\hline \multirow{2}{*}{ Level $^{\mathbf{a}}$} & \multicolumn{2}{c}{$\begin{array}{c}\text { Lincoln Lake } \\
(\mathbf{p}=\mathbf{0 . 1 5 7 5})^{\mathbf{b}}\end{array}$} & \multicolumn{2}{c}{$\begin{array}{c}\text { Moores Creek } \\
(\mathbf{p}=\mathbf{0 . 9 3 2 8})^{\mathbf{c}}\end{array}$} & \multicolumn{2}{c}{$\begin{array}{c}\text { Beatty Branch } \\
(\mathbf{p}=\mathbf{0 . 8 1 5 4})^{\mathbf{d}}\end{array}$} \\
\cline { 2 - 7 } & Locals & Outsiders & Locals & Outsiders & Locals & Outsiders \\
\hline Agree & 75.4 & 57.9 & 52.5 & 50.0 & 47.0 & 44.4 \\
Neutral & 21.4 & 42.1 & 38.5 & 38.9 & 41.7 & 50.0 \\
Disagree & 3.2 & 0.0 & 9.0 & 11.1 & 11.3 & 5.6 \\
\hline
\end{tabular}

${ }^{\mathrm{a}}$ Table entry as a percentage of respondents in that group selecting that response. ${ }^{\mathrm{b}}$ Response group includes 126 of the 131 Locals and 18 of 18 Outsiders. 'Response group includes 122 of the 131 Locals and 18 of 18 Outsiders. ${ }^{\mathrm{d}}$ Response group includes 115 of the 131 Locals and 18 of 18 Outsiders.

Table 4. General perceptions that water is good for swimming in the Lincoln Lake watershed, lakes and streams (percentage of respondents).

\begin{tabular}{ccccccc}
\hline \multirow{2}{*}{ Level $^{\mathbf{a}}$} & \multicolumn{2}{c}{$\begin{array}{c}\text { Lincoln Lake } \\
(\mathbf{p}=\mathbf{0 . 2 7 9 6})^{\mathbf{b}}\end{array}$} & \multicolumn{2}{c}{$\begin{array}{c}\text { Moores Creek } \\
(\mathbf{p}=\mathbf{0 . 7 2 8 9})^{\mathbf{c}}\end{array}$} & \multicolumn{2}{c}{$\begin{array}{c}\text { Beatty Branch } \\
(\mathbf{p}=\mathbf{0 . 7 2 4 3})^{\mathbf{d}}\end{array}$} \\
\cline { 2 - 7 } & Locals & Outsiders & Locals & Outsiders & Locals & Outsiders \\
\hline Agree & 38.9 & 22.2 & 32.2 & 22.2 & 30.4 & 22.2 \\
Neutral & 36.5 & 55.6 & 42.2 & 50.0 & 44.4 & 55.6 \\
Disagree & 24.6 & 22.2 & 25.6 & 27.8 & 25.2 & 22.2 \\
\hline
\end{tabular}

${ }^{\mathrm{a}}$ Table entry as a percentage of respondents in that group selecting that response. ${ }^{\mathrm{b}}$ Response group includes 126 of the 131 Locals and 18 of 18 Outsiders. ${ }^{c}$ Response group includes 121 of the 131 Locals and 18 of 18 Outsiders. ${ }^{\mathrm{d}}$ Response group includes 115 of the 131 Locals and 18 of 18 Outsiders.

groups to water quality problems in the LLW (Table 5). Again, only answers from Outsiders familiar with the LLW were used in this analysis.

Significant differences existed in stakeholder perceptions regarding different groups' contributions to water quality degradation. For instance, most Locals believed that agriculture either did not contribute at all (13\%) or contributed only a small amount (64\%) to water quality problems in the LLW. On the other hand, $61 \%$ of Outsiders believed that agriculture's contribution was large. Additionally, with the exception of new construction, less than $30 \%$ of the Locals believed any one source was largely responsible for water quality degradation while over $50 \%$ of the Outsiders felt four sources were largely responsible for water quality degradation.

Some similarities in perceptions can be drawn from the results. First, overall, both stakeholder groups believed that all listed sources in Table 5 contributed at least small amounts to water degradation; the relative 
ranking of those sources as contributors between stakeholder groups was what differed (Table 5). New construction was chosen most often by both Locals and Outsiders as a large contributor of water quality degradation but the magnitude of agreement between Locals and Outsiders differed considerably ( $46 \%$ vs. $77 \%$ respectively).

As expected, while significant differences existed between Locals and Outsiders perceptions of which potential source group(s) was/were responsible for water pollution cleanup, some similarities were found too (Table 6). Both Locals and Outsiders believed that all potential source groups shared some responsibility for cleaning up. Locals and Outsiders both identified most often new construction, industry, and the city sewer system as holding large responsibilities for cleaning up, but the magnitude attributed to each potential source differed across stakeholder groups. However, nearly three times as many Outsiders (67\%) than Locals (24\%) believed that agricultural producers are largely responsible for cleanup.

Interesting changes were found in distribution of none, small and large between potential source and responsibility perceptions for both Locals and Outsiders. When comparing Table 5 and Table 6, for any given poten-

Table 5. Perceptions of the amount of contribution of different groups to water quality problems in nutrient surplus areas including the Lincoln Lake watershed (percentage of respondents).

\begin{tabular}{cccccccc}
\hline & \multicolumn{5}{c}{ Locals } & \multicolumn{5}{c}{ Outsiders } \\
\cline { 2 - 6 } Group $^{\mathrm{a}}$ & None & Small & Large & None & Small & Large & p-value \\
\hline Agricultural Producers $^{\mathrm{b}}$ & 13.0 & 64.2 & 22.8 & 0.0 & 38.9 & 61.1 & 0.0036 \\
City Sewer System $^{\mathrm{c}}$ & 16.2 & 55.6 & 28.2 & 0.0 & 33.3 & 66.7 & 0.0041 \\
Households $^{\mathrm{d}}$ & 19.0 & 57.0 & 24.0 & 0.0 & 72.2 & 27.8 & 0.1074 \\
Industry $^{\mathrm{e}}$ & 22.1 & 48.4 & 29.5 & 0.0 & 41.2 & 58.8 & 0.0142 \\
New Construction $^{\mathrm{f}}$ & 14.9 & 39.7 & 45.5 & 0.0 & 23.5 & 76.5 & 0.0435 \\
Outdoor Recreation $^{\mathrm{g}}$ & 52.5 & 40.7 & 6.8 & 16.7 & 83.3 & 0.0 & 0.0033 \\
\hline
\end{tabular}

${ }^{\mathrm{a}}$ Table entry as a percentage of respondents in that group selecting that response. ${ }^{\mathrm{b}}$ Response group includes 123 of the 131 Locals and 18 of 18 Outsiders. 'Response group includes 117 of the 131 Locals and 18 of 18 Outsiders. ${ }^{\mathrm{d}}$ Response group includes 121 of the 131 Locals and 18 of 18 Outsiders. ${ }^{\mathrm{e}}$ Response group includes 122 of the 131 Locals and 18 of 18 Outsiders. ${ }^{f}$ Response group includes 121 of the 131 Locals and 17 of 18 Outsiders. ${ }^{\mathrm{g}}$ Response group includes 118 of the 131 Locals and 18 of 18 Outsiders.

Table 6. Perceptions of responsibility of cleaning up of different groups to improve water quality in nutrient surplus areas including the Lincoln Lake watershed (percentage of respondents).

\begin{tabular}{cccccccc}
\hline & \multicolumn{5}{c}{ Locals } & \multicolumn{5}{c}{ Outsiders } & p-value \\
\cline { 2 - 6 } Group $^{\mathrm{a}}$ & None & Small & Large & None & Small & Large & \\
\hline Agricultural Producers $^{\mathrm{b}}$ & 20.8 & 55.0 & 24.2 & 0.0 & 33.3 & 66.7 & 0.0007 \\
City Sewer System $^{\mathrm{c}}$ & 18.1 & 49.1 & 32.8 & 0.0 & 22.2 & 77.8 & 0.0010 \\
Households $^{\mathrm{d}}$ & 19.8 & 55.2 & 25.0 & 5.9 & 64.7 & 29.4 & 0.4582 \\
Industry $^{\mathrm{e}}$ & 13.0 & 47.8 & 39.1 & 0.0 & 38.9 & 61.1 & 0.1218 \\
New Construction $^{\mathrm{f}}$ & 11.9 & 39.0 & 49.2 & 0.0 & 22.2 & 77.8 & 0.0681 \\
Outdoor Recreation $^{\mathrm{g}}$ & 47.3 & 42.0 & 10.7 & 16.7 & 83.3 & 0.0 & 0.0047 \\
\hline
\end{tabular}

${ }^{\mathrm{a}}$ Table entry as a percentage of respondents in that group selecting that response. ${ }^{\mathrm{b}}$ Response group includes 120 of the 131 Locals and 18 of 18 Outsiders. 'Response group includes 116 of the 131 Locals and 18 of 18 Outsiders. ${ }^{\mathrm{d}}$ Response group includes 116 of the 131 Locals and 18 of 18 Outsiders. ${ }^{\mathrm{e}}$ Response group includes 115 of the 131 Locals and 18 of 18 Outsiders. ${ }^{\mathrm{f}}$ Response group includes 118 of the 131 Locals and 18 of 18 Outsiders. ${ }^{g}$ Response group includes 112 of the 131 Locals and 18 of 18 Outsiders. 
tial source except recreation, a greater percentage of both Locals and Outsiders respondents put more responsibility on these sources for cleanup than they did for water quality pollution. Similarly a greater percentage of both Locals and Outsiders said these sources were not responsible for cleanup compared to the percentages that believed these sources were not responsible for the water quality problems. It suggests that those who place small responsibility on each of these potential sources as causes of the degradation of water quality were split in their opinion as to how much responsibility to assign them for cleanup.

\subsection{Perceptions Regarding Effectiveness and Affordability of Best Management Practices}

Only Locals and those Outsiders familiar with the LLW were asked whether they agreed that each of 15 BMPs was effective in reducing sediment and/or nutrient loss from agricultural land. The possible responses were "yes", "no" and "not sure.” The percentage responses of each group are presented in Table 7.

There are four important points to note about this analysis. First, for any of the 15 practices listed, 17 to 26 percent of the 149 potential respondents did not answer the question. Second, significant differences were found in Locals and Outsiders perceptions for 11 of the 15 BMPs. In general, a larger percentage of Outsiders thought the BMPs were effective while a larger percentage of Locals were unsure of BMP effectiveness. The reason for these differences may be because Outsiders are more likely to be exposed to BMPs through their work than Locals not directly engaged in agriculture.

Third, there were no significant differences between opinions of Locals and Outsiders for four of the 15 BMPs: controlled grazing, prescribed grazing, soil testing, and use of legumes to reduce $\mathrm{N}$ application. In general, both Locals and Outsiders believed that controlled grazing and soil testing were effective BMPs. But both groups were more uncertain about the effectiveness of prescribed grazing and using legumes to reduce $\mathrm{N}$ application. Fourth, the affordability of BMPs was directly asked to agricultural producers (a subset of the Locals) and only to Outsiders familiar with the LLW. In general, agricultural producers and Outsiders believed that agricultural producers can afford to adopt BMPs.

\begin{tabular}{|c|c|c|c|c|c|c|c|c|}
\hline \multirow{2}{*}{ Best Management Practice } & \multirow{2}{*}{$\begin{array}{c}\text { Total }^{\mathrm{a}} \\
\text { Responses }^{2}\end{array}$} & \multicolumn{3}{|c|}{ Locals } & \multicolumn{3}{|c|}{ Outsiders } & \multirow{2}{*}{ p-value } \\
\hline & & No & Yes & Not Sure & No & Yes & Not Sure & \\
\hline Controlled Grazing & 121 & 10.7 & 75.7 & 13.6 & 0.0 & 94.4 & 5.6 & 0.2395 \\
\hline Filter Strips/Riparian Buffers & 118 & 5.0 & 59.0 & 36.0 & 0.0 & 100.0 & 0.0 & 0.0014 \\
\hline Prescribed Grazing & 117 & 16.2 & 53.5 & 30.3 & 0.0 & 72.2 & 27.8 & 0.1501 \\
\hline Pasture Grass Management & 120 & 7.8 & 70.6 & 21.6 & 0.0 & 100.0 & 0.0 & 0.0264 \\
\hline Stream Bank Stabilization & 117 & 13.1 & 47.5 & 39.4 & 5.6 & 94.4 & 0.0 & 0.0003 \\
\hline Cattle Track Stabilization & 110 & 10.8 & 47.3 & 41.9 & 0.0 & 88.2 & 11.8 & 0.0066 \\
\hline Stream Fencing & 116 & 18.4 & 49.0 & 32.6 & 0.0 & 88.9 & 11.1 & 0.0054 \\
\hline Basin Fertilizer Application & 123 & 5.7 & 73.3 & 21.0 & 0.0 & 100.0 & 0.0 & 0.0376 \\
\hline Litter Storage Shed & 119 & 16.8 & 49.5 & 33.7 & 22.2 & 77.8 & 0.0 & 0.0039 \\
\hline Manure Composting & 114 & 9.4 & 49.0 & 41.6 & 27.8 & 55.6 & 16.6 & 0.0356 \\
\hline Soil Testing & 124 & 5.7 & 80.2 & 14.2 & 11.1 & 88.9 & 0.0 & 0.1482 \\
\hline $\begin{array}{l}\text { Use of Legumes to Reduce } \\
\text { NApplication }\end{array}$ & 114 & 6.2 & 60.8 & 33.0 & 23.5 & 58.8 & 17.7 & 0.0595 \\
\hline Nutrient Management Plan & 118 & 9.0 & 52.0 & 39.0 & 5.6 & 88.9 & 5.5 & 0.0058 \\
\hline $\begin{array}{c}\text { Manure instead of Commercial } \\
\text { Fertilizer }\end{array}$ & 121 & 7.8 & 68.0 & 24.3 & 27.8 & 72.2 & 0.0 & 0.0037 \\
\hline Waste Treatment Lagoon & 116 & 19.4 & 17.4 & 63.3 & 11.1 & 77.8 & 11.1 & $<0.0001$ \\
\hline
\end{tabular}

${ }^{\mathrm{a}}$ Table entry as a percentage of respondents in that group selecting that response. 
Significant differences in perceptions regarding only two BMPs (nutrient management plan (NMP) and waste treatment lagoon) were found (Table 8). Surprisingly, only 68\% of the agricultural producers believed that NMPs are affordable. This is a low cost practice encouraged by county, state, and federal agencies and institutions. It could have been possible that the agricultural producers and perhaps, some producers thought that the NMP was unaffordable because it could have limited how much they fertilized, which could have reduced their yield, and as a result their carrying capacity or hay sales. According to J. Pennington (personal communication, January 30, 2014), even though conservation plans have been around for decades, the transition from the conservation plan to the NMP was still new among some of the population and they could have been unfamiliar with the new process.

\subsection{Perceptions Regarding Interactions with the Government}

For this section of the survey, the Locals group was disaggregated into agricultural producers (Table 9) and residents (Table 10) to ask each group specific perceptions regarding what level of government (i.e., county, state, federal) best represents their water quality needs and concerns.

Outsiders were also asked their perceptions of what level of government they thought represented agricultural producers' and residents' water quality needs and concerns best. A Fisher's exact test found a significant difference between agricultural producers' and Outsiders' responses $(\mathrm{p}<0.0001)$. Agricultural producers indicated that the county government represented them best while Outsiders believed that all levels—county, state and federal—of government represented agricultural producers' interests (Table 9) about equally well.

The reasons for these differences could be that while agricultural producers generally have more direct interaction with officials on the county level, the Outsiders surveyed represented all levels of government and are working to advance agriculture in the state as a whole. On the other hand, no significant difference in opinions between residents and Outsiders was found $(\mathrm{p}=0.5252)$. Both residents and Outsiders believed that the county government represented residents' water quality interests and concerns best (Table 10).

Table 8. Perceptions that agricultural producers can afford adopting best management practices in their lands (percentage of respondents).

\begin{tabular}{|c|c|c|c|c|c|c|}
\hline \multirow{2}{*}{ Group } & \multirow{2}{*}{$\begin{array}{c}\text { Total }^{\mathrm{a}} \\
\text { Responses }^{2}\end{array}$} & \multicolumn{2}{|c|}{ Agricultural Producers } & \multicolumn{2}{|c|}{ Outsiders } & \multirow{2}{*}{ p-value } \\
\hline & & No & Yes & No & Yes & \\
\hline Controlled Grazing & 71 & 24.5 & 75.5 & 5.6 & 94.4 & 0.0981 \\
\hline Filter Strips/Riparian Buffers & 68 & 42.0 & 58.0 & 38.9 & 61.1 & $>0.9999$ \\
\hline Prescribed Grazing & 59 & 27.9 & 72.1 & 6.3 & 93.7 & 0.0903 \\
\hline Pasture Grass Management & 71 & 18.9 & 81.1 & 16.7 & 83.3 & $>0.9999$ \\
\hline Stream Bank Stabilization & 73 & 76.4 & 23.6 & 83.3 & 16.7 & 0.7453 \\
\hline Cattle Track Stabilization & 65 & 38.0 & 62.0 & 53.3 & 46.7 & 0.3739 \\
\hline Stream Fencing & 73 & 78.2 & 21.8 & 61.1 & 38.9 & 0.1316 \\
\hline Basin Fertilizer Application & 70 & 17.3 & 82.7 & 11.1 & 88.9 & 0.7162 \\
\hline Litter Storage Shed & 72 & 64.8 & 35.2 & 55.6 & 44.4 & 0.5770 \\
\hline Manure Composting & 61 & 47.7 & 52.3 & 41.2 & 58.9 & 0.7767 \\
\hline Soil Testing & 74 & 8.9 & 91.1 & 0.0 & 100.0 & 0.3263 \\
\hline Use of Legumes to Reduce N Application & 65 & 17.0 & 83.0 & 38.9 & 61.1 & 0.0977 \\
\hline Nutrient Management Plan & 68 & 32.0 & 68.0 & 5.6 & 94.4 & 0.0288 \\
\hline Manure instead of Commercial Fertilizer & 69 & 7.8 & 92.2 & 11.1 & 88.9 & 0.6473 \\
\hline Waste Treatment Lagoon & 58 & 85.7 & 14.3 & 56.2 & 43.8 & 0.0310 \\
\hline
\end{tabular}

${ }^{\mathrm{a}}$ Table entry as a percentage of respondents in that group selecting that response. 
Table 9. Perceptions that a specific level of government represents agricultural producers water quality needs and concerns best (percentage of respondents).

\begin{tabular}{ccc}
\hline Government Level $^{\mathrm{a}}$ & Agricultural Producers & Outsiders \\
\hline County & 83.1 & 36.2 \\
State & 13.6 & 37.7 \\
Federal & 3.4 & 26.1 \\
\hline
\end{tabular}

${ }^{\mathrm{a}}$ Table entry as a percentage of respondents in that group selecting that response. Response group includes 59 of the 63 agricultural producers and 69 of 78 Outsiders.

Table 10. Perceptions that a specific level of government represents the residents' water quality needs and concerns best (percentage of respondents).

\begin{tabular}{ccc}
\hline Government Level $^{\mathbf{a}}$ & Residents & Outsiders \\
\hline County & 69.2 & 60.3 \\
State & 23.1 & 26.5 \\
Federal & 7.7 & 13.2 \\
\hline
\end{tabular}

${ }^{\mathrm{a}}$ Table entry as a percentage of respondents in that group selecting that response. Response group includes 52 of the 68 residents and 68 of 78 Outsiders.

Agricultural producers and Outsiders were asked their opinion of whether additional power/authority should be given to each level of government to address water quality in the LLW. While no significant differences were found, the data did provide the following insights. The greatest percentages of agricultural producers and Outsiders believed that County government should be given at least some additional power to address water quality concerns (Table 11).

The smallest percentages of agricultural producers and Outsiders believed Federal government should receive some or a lot of additional power. Interestingly as well, $71 \%$ of Outsiders vs. only $48 \%$ of agricultural producers thought some or a lot of additional power should be given to state government. This may be because state government offices oversee most of the water quality regulation and a large percentage of the surveyed Outsiders are employed by state government.

The perceived importance of the county government over the state government by the residents group could be explained by the fact that residents were more willing to give additional power to a government entity that is familiar with their local water quality problems and consequently, could represent their water quality needs and concerns better (Table 12).

Although no significant differences were found (at the 5\% level of significance) when Residents and Outsiders were asked about giving additional power to the state government, $59 \%$ of the residents felt that the state government should not receive additional power. Only $29 \%$ of the outsiders felt in the same way. In fact, $24 \%$ of the Outsiders believed that the state government should receive a lot of additional power compared to $9 \%$ of the residents. However, both groups' opinions were very similar regarding the federal government.

\section{Discussion}

The survey analysis fulfilled the goal of providing research and outreach personnel with information regarding the perceptions of key stakeholders regarding water quality. In many cases, it revealed significant differences in perceptions between those who lived and worked in the watershed (Locals) and water quality specialists (Outsiders). Gaps in knowledge regarding water quality and BMPs were identified and addressed by the CEAP 
Table 11. Perceptions that additional power/authority should be given to each level of government to address water quality (Agricultural Producers vs. Outsiders).

\begin{tabular}{ccccccccc}
\hline \multirow{2}{*}{ Government $^{\mathbf{a}}$} & \multicolumn{3}{c}{ Agricultural Producers } & \multicolumn{3}{c}{ Outsiders } & \multirow{2}{*}{ p-value } \\
\cline { 2 - 7 } & None & Some & A lot & None & Some & A lot & \\
\hline County & 26.6 & 31.7 & 41.7 & 41.2 & 23.5 & 35.3 & 0.6104 \\
State & 51.7 & 36.7 & 11.6 & 29.4 & 47.1 & 23.5 & 0.2116 \\
Federal & 81.7 & 13.3 & 5.0 & 70.1 & 23.5 & 5.9 & 0.5652 \\
\hline
\end{tabular}

${ }^{\mathrm{a}}$ Table entry as a percentage of respondents in that group selecting that response. Response group includes 60 of the 63 agricultural producers and 17 of 18 Outsiders.

Table 12. Perceptions that additional power/authority should be given to each level of government to address water quality (Residents vs. Outsiders).

\begin{tabular}{cccccccc}
\hline \multirow{2}{*}{ Government $^{\mathbf{a}}$} & \multicolumn{3}{c}{ Residents } & \multicolumn{3}{c}{ Outsiders } & p-value \\
\cline { 2 - 7 } & None & Some & A lot & None & Some & A lot & \\
\hline County & 32.8 & 31.0 & 36.2 & 41.2 & 23.5 & 35.3 & 0.7883 \\
State & 58.9 & 32.1 & 9.0 & 29.4 & 47.1 & 23.5 & 0.0661 \\
Federal & 69.2 & 28.9 & 1.9 & 70.1 & 23.5 & 5.9 & 0.6360 \\
\hline
\end{tabular}

${ }^{\text {a }}$ Table entry as a percentage of respondents in that group selecting that response. Response group includes 55 of the 63 agricultural producers and 17 of 18 Outsiders.

project team through extensive outreach efforts in the LLW that included over two dozen community based meetings attended by more than 1000 diverse stakeholders. Through these meetings, science based information regarding: 1) causes of water quality problems, 2) responsibilities for water quality improvement, and 3) effectiveness and affordability of BMPs were shared.

One important survey result for the CEAP team was the perception by some agricultural producers that NMPs were not affordable. In fact, only $39 \%$ of the LLW agricultural producers had implemented a NMP at the time they were surveyed. Based on these survey results, the CEAP project team focused in part on educational meetings, face-to-face interviews and farm visits to promote a sign up campaign for NMP implementation. This campaign was a cooperative effort between the Natural Resources Conservation Services, the Washington County Conservation District, and the Washington County Cooperative Extension Service. The results of this campaign included over 1000 producers in Washington County and several surrounding counties who were exposed to information regarding NMPs and BMPs. Additionally, NMP adoption within the watershed increased by 66\% (45 new NMPs) and 77 other NMPs were adopted adjacent to the LLW. Furthermore, 3525 ha (8710 ac), in and adjacent to the watershed were soil sampled.

A second important survey result also pointed to differences in perception between Locals and Outsiders regarding BMP effectiveness. The CEAP team conducted a BMP awareness and education campaign in conjunction with a stewardship recognition program. Through this campaign, 25 agricultural producers in the LLW implemented at least one new BMP on their farms. Additionally, 54 participants who were implementing BMPs on their farms received a stewardship recognition sign that was displayed by a road adjacent to their farm. The goal of these signs was two-fold: 1) to recognize producers who were implementing BMPs and 2) to increase awareness of BMP use on farms to others in the community.

A third important survey result indicated that Locals, especially agricultural producers, felt disengaged from water conservation policy. Specifically, agricultural producers perceived that county officials represented their needs better than state and federal officials did. Yet these county officials needed more power to address water quality concerns. The CEAP project team shared the results with watershed organizations, state and federal agencies, and other stakeholders across the state of Arkansas. Subsequent input from agricultural producers to local officials have resulted in changes to some county level conservation program efforts and increased producer participation. However, at the same time millions of dollars available through a non-county level conser- 
vation program in the watershed go unused; producers state that the program (which did not include producer input) does not meet their needs.

Thanks in large part due to information gleamed from the survey, the CEAP team was able to mount a successful education campaign within LLW that raised awareness of water quality issues and effected the adoption of BMPs. The impacts were not limited to LLW Locals stakeholders. Others recognizing the success in LLW adopted the CEAP model to provide watershed relevant water quality education and the enactment of the "stewardship sign program” in the greater Illinois River Watershed and War Eagle Watershed of the White River.

\section{Conclusions}

Analysis of the survey responses provided timely information regarding the water quality perceptions of key stakeholders in the LLW. By sharing survey results with Locals stakeholders and Outsiders, the CEAP project team improved stakeholders' inclusion, trust, cooperation and base knowledge about causes and potential solutions to water quality degradation.

This study provides a list of lessons learned:

- Availability of technical information regarding water quality, BMPs' effectiveness and BMP affordability does not guarantee that all types of stakeholders will be familiar with BMPs, even in a nutrient surplus watershed.

- Understanding stakeholders' water quality perceptions and using that information to create education and outreach programs is a first step in addressing the water quality issue.

- Engagement of key stakeholders is fundamental in the development of local policies to water quality problems.

- Educational programs, developed through assessments of stakeholder perceptions can results in actions that can improve water quality in a nutrient surplus watershed.

Lessons learned from this collaborative approach could be transferred to other nutrient surplus watersheds to develop education campaigns and stewardship recognition programs to improve water quality in the region.

\section{Acknowledgements}

Funding for this research was provided in part by the USDA-CSREES under Conservation Effects Assessment Project Grant Program (award 2005-04333).

\section{References}

[1] Imperial, M.T. (2005) Using Collaboration as a Governance Strategy: Lessons from Six Watershed Management Programs. Administration \& Society, 37, 281-320. http://dx.doi.org/10.1177/0095399705276111

[2] Lubell, M. and Fulton, A. (2008) Local Policy Networks and Agricultural Watershed Management. Journal of Public Administration Research and Theory, 18, 673-696. http://dx.doi.org/10.1093/jopart/mum031

[3] Osmond, D., Meals, D., Hoag, D., Arabi, M., Luloff, A., Jennings, G. and Line, D. (2012) Improving Conservation Practices Programming to Protect Water Quality in Agricultural Watersheds: Lessons Learned from the National Institute of Food and Agriculture-Conservation Effects Assessment Project. Journal of Soil and Water Conservation, 67, 122A-127A. http://dx.doi.org/10.2489/jswc.67.5.122A

[4] Savage, J. and Ribaudo, M.O. (2013) Impact of Environmental Policies on the Adoption of Manure Management Practices in the Chesapeake Bay Watershed. Journal of Environmental Management, 129, 143-148. http://dx.doi.org/10.1016/i.jenvman.2013.06.039

[5] Scheberle, D. (2004) Federalism and Environmental Policy: Trust and the Politics of Implementation. Georgetown University Press, Washington DC.

[6] Grimble, R. and Wellard, K. (1997) Stakeholder Methodologies in Natural Resource Management: A Review of Principles, Contexts, Experiences and Opportunities. Agricultural Systems, 55, 173-193. http://dx.doi.org/10.1016/S0308-521X(97)00006-1

[7] Ravnborg, H.M. and Westermann, O. (2002) Understanding Interdependencies: Stakeholder Identification and Negotiation for Collective Natural Resource Management. Agricultural Systems, 73, 41-56. http://dx.doi.org/10.1016/S0308-521X(01)00099-3

[8] Mostashari, A. and Sussman, J. (2005) Stakeholder-Assisted Modeling and Policy Design Process for Environmental Decision-Making. Journal of Environmental Assessment Policy \& Management, 7, 355-386. 
http://dx.doi.org/10.1142/S1464333205002110

[9] Brugnach, M., Dewulf, A., Henriksen, H.J. and van der Keur, P. (2011) More Is Not Always Better: Coping with Ambiguity in Natural Resources Management. Journal of Environmental Management, 92, 78-84. http://dx.doi.org/10.1016/j.jenvman.2010.08.029

[10] Barnes, A.P., Willock, J., Hall, C. and Toma, L. (2009) Farmer Perspectives and Practices Regarding Water Pollution Control Programmes in Scotland. Agricultural Water Management, 96, 1715-1722. http://dx.doi.org/10.1016/j.agwat.2009.07.002

[11] Barnes, A.P., Willock, J., Toma, L. and Hall, C. (2011) Utilising a Farmer Typology to Understand Farmer Behaviour towards Water Quality Management: Nitrate Vulnerable Zones in Scotland. Journal of Environmental Planning and Management, 54, 477-494. http://dx.doi.org/10.1080/09640568.2010.515880

[12] Borisova, T., Racevskis, L. and Kipp, J. (2012) Stakeholder Analysis of a Collaborative Watershed Management Process: A Florida Case Study. Journal of the American Water Resources Association, 48, 277-296. http://dx.doi.org/10.1111/j.1752-1688.2011.00615.x

[13] Kay, P., Grayson, R., Phillips, M., Stanley, K., Dodsworth, A., Hanson, A., Walker, A., Foulger, M., McDonnell, I. and Taylor, S. (2012) The Effectiveness of Agricultural Stewardship for Improving Water Quality at the Catchment Scale: Experiences from an NVZ and ECSFDI Watershed. Journal of Hydrology, 422-423, 10-16. http://dx.doi.org/10.1016/j.jhydrol.2011.12.005

[14] Williams, J.R., Smith, C.M., Roe, J.D., Leatherman, J.C. and Wilson, R.M. (2012) Engaging Watershed Stakeholders for Cost-Effective Environmental Management Planning with "Watershed Manager.” Journal of Natural Resources \& Life Sciences Education, 41, 44-53.

[15] Popp, J., Rodríguez, H.G., Gbur, E. and Pennington, J. (2007) The Role of Stakeholders’ Perceptions in Addressing Water Quality Disputes in an Embattled Watershed. Journal of Environmental Monitoring and Restoration, 3, 255-263. http://dx.doi.org/10.4029/2007jemrest3no125

[16] Sang, N. (2008) Informing Common Pool Resource Problems: A Survey of Preference for Catchment Management Strategies amongst Farmers and the General Public in the Ythan River Catchment. Journal of Environmental Management, 88, 1161-1174. http://dx.doi.org/10.1016/j.jenvman.2007.06.014

[17] Riley, T. and Barr, L. (2008) Partners in Protecting Arkansas’ Water Bodies. University of Arkansas, Little Rock.

[18] Hoag, D.L.K., Chaubey, I., Popp, J., Gitau, M., Chang, L., Pennington, J., Rodríguez, H.G., Gbur, E., Nelson, M. and Sharpley, A.N. (2012) Lincoln Lake Watershed, Arkansas: National Institute of Food and Agriculture-Conservation Effects Assessment Project. In: Osmond, D.L., Meals, D.W., Hoag, D.L.K. and Arabi, M., Eds., How to Build Better Agricultural Conservation Programs to Protect Water Quality, Soil and Water Conservation Society, Ankeny, 171200.

[19] Chiang, L., Chaubey, I., Gitau, M. and Arnold, J.G. (2010) Differentiating Impacts of Land Use Changes from Pasture Management in a CEAP Watershed Using the SWAT Model. Transactions of the American Society of Agricultural Engineers, 53, 1569-1584.

[20] Chaubey, I., Chiang, L., Gitau, M. and Mohamed, S. (2010) Effectiveness of BMPs in Improving Water Quality in a Pasture Dominated Watershed. Journal of Soil and Water Conservation, 65, 424-437. http://dx.doi.org/10.2489/jswc.65.6.424

[21] Gitau, M., Chaubey, I., Gbur, E., Pennington, J. and Gorham, B. (2010) Impact of Land Use Change and BMP Implementation on Water Quality in a Pastured Northwest Arkansas Watershed. Journal of Soil and Water Conservation, 65, 353-368. http://dx.doi.org/10.2489/jswc.65.6.353

[22] Vendrell, P.F., Steele, K.F., Nelson, M.A. and Cash, W.L. (2000) Extended Water Quality Monitoring of the Lincoln Lake Watershed. Arkansas Water Resources Center Report MSC-296, University of Arkansas, Fayetteville.

[23] Nelson, M.A., Cash, L.W. and Trost, G.K. (2004) Water Quality Monitoring of Moores Creek above Lincoln Lake 2003. Arkansas Water Resources Center Report MSC-319, University of Arkansas, Fayetteville.

[24] Bailey, B.W., Haggard, B.E. and Massey, L.B. (2012) Water Quality Trends across Select 319 Monitoring Sites in Northwest Arkansas. Arkansas Water Resources Center Report MSC-365, University of Arkansas, Fayetteville. 